\title{
Dry air- and hypertonic aerosol-induced bronchoconstriction and cellular responses in the canine lung periphery
}

\author{
A.N. Freed, C. Omori, W.C. Hubbard, N.F. Adkinson Jr
}

Dry air-and hypertonic aerosol-induced bronchoconstriction and cellular responses in the canine lung periphery. A.N. Freed, C. Omori, W.C. Hubbard, N.F. Adkinson Jr. CERS Journals Ltd 1994.

ABSTRACT: Dry air and hypertonic saline both create an osmotic stress to the airways, whilst dry air alone induces transient cooling of the airway mucosa. It is unclear whether these two stimuli lead to bronchoconstriction via the same mechanisms.

We compared airflow- and hypertonic aerosol-induced bronchoconstriction (AIB and HIB, respectively) in the canine lung periphery, using a wedged bronchoscope to measure collateral system resistance (Rcs). Bronchoalveolar lavage (BAL) was used to examine changes in cells and mediators during AIB and HIB.

We found that: 1) peripheral airways are not refractory to either dry air or hypertonic aerosols, and do not exhibit cross-refractoriness to these stimuli; 2) differences in strength of stimulus can alter the magnitude but not the time course of HIB; 3) within an individual, AIB and HIB are significantly correlated; 4) epithelial cells recovered in BAL fluid (BALF) are significantly elevated after AIB, and are similarly increased after HIB; 5) when compared to control, mediators recovered in BALF are significantly elevated after AIB but not HIB; 6) HIB is not altered by cyclo-oxygenase inhibition; and 7) lavage with hypertonic fluid does not affect the number of epithelial cells recovered, although the concentrations of some mediators are increased.

We speculate that differences in cell and mediator profiles reflect differences in the time course of AIB and HIB that result from the modulation of temperature sensitive pathways that occurs during dry air, but not during hypertonic aerosol challenge.

Eur Respir J., 1994, 7, 1308-1316.
Depts of Environmental Health Sciences and Medicine, The Johns Hopkins University, Baltimore, Maryland, USA.

Correspondence: A.N. Freed

Division of Physiology

7006 Hygiene

The Johns Hopkins University

615 North Wolfe Street

Baltimore

Maryland 21205

USA

Keywords: Airway reactivity

bronchoalveolar lavage

bronchoconstriction

collateral resistance

exercise-induced asthma

refractory period

Received: October 71993

Accepted after revision February 231994

This research was supported in part by NHLBI R29 HL39406 and SCOR HL37119.
Evaporative water loss occurs during hyperventilation [1], and is believed to initiate airflow inducedbronchoconstriction (AIB) in individuals with asthma $[2,3]$. Smith and Anderson [2] estimated that the respiratory water loss associated with hyperpnoea and hypertonic aerosol challenges was similar, and concluded that hyperventilation resulted in airway hypertonicity. The fact that hypertonicity stimulates mast cell mediator release in vitro [4], and was implicated to do so in vivo [5], is consistent with this hypothesis. However, this scenario is complicated by the fact that data from man and dog suggest that the stimulatory effects of evaporative water loss may be counterbalanced by an inhibitory pathway associated with airway cooling [69].

Hyperventilation of canine peripheral airways with dry air produces physiological responses similar to those exhibited by asthmatic subjects after exercising or after hyperventilating cold, dry air [10]. Airway mucosal cell damage, as assessed by differential cell analysis of bronchoalveolar lavage fluid (BALF), is associated with AIB in canine peripheral airways [11], and in asthmatic humans [12]. BALF cell profile data also suggest that challenge with warm, wet air $[10,11$, $13]$, and pretreatment with $\beta$-agonists $[14,15]$, attenuate AIB and significantly protect the canine mucosa from airway desiccation, when compared to untreated dry air challenged segments. In addition to $\beta$-agonists [14-16], methylxanthines [16, 17], muscarinic receptor antagonists $[13,18]$, cyclo-oxygenase inhibitors $[11,13$, 19], leukotriene antagonists [20, 21], and airway cooling [6-9] reduce or abolish AIB in canine peripheral airways and individuals with asthma.

The magnitude of hypertonic aerosol-induced bronchoconstriction (HIB) in man and dog is positively correlated with the magnitude of AIB [22-26]. However, significant differences exist in the time course and the magnitude of responses elicited by these two stimuli: in contrast to AIB, which develops slowly after challenge, HIB appears to be initiated during the challenge [23]. 
This difference was also noted in asthmatic subjects [25], and may, in part, be explained by the absence of cooling during hypertonic aerosol challenge. When canine peripheral airways are artificially cooled and simultaneously exposed to a hypertonic aerosol, the onset of HIB is delayed in a manner similar to AIB [8]. This is consistent with the hypothesis that dry air and hypertonic aerosol activate portions of the same regulatory pathway.

In this study, we examined the phenomenon of crossrefractoriness, i.e. whether HIB or AIB alters airway responsiveness to a subsequent challenge with either dry air or hypertonic aerosol, respectively. It was suggested that cross-refractoriness supported the hypothesis that hypertonicity and exercise initiated bronchoconstriction via a common final pathway [27]. Based on previous studies $[10,23,28]$, we would predict that cross-refractoriness would not be exhibited by canine peripheral airways. However, it was important to test this, because if canine peripheral airways were not refractory to either dry air or hypertonic solutions but were cross-refractory to these stimuli, then the model would be inconsistent with the human analogue [27], and its applicability would be of limited value. In an attempt to further delineate the mechanisms responsible for AIB and HIB, we: 1) compared cell and mediator profiles recovered in BALF after AIB and HIB; 2) determined the effects of indomethacin on HIB for comparison to its effect on AIB; and 3) lavaged peripheral airways with hypertonic BALF and determined its effect on cell and mediator profiles. This last protocol was performed to ensure that the peripheral airways were exposed to a known hypertonic stimulus.

\section{Methods}

All experimental methods and protocols were approved by the Johns Hopkins Medical Institution's Animal Care and Use Committee.

\section{Measurement of collateral resistance}

Male mongrel dogs $(20.1 \pm 0.6 \mathrm{~kg}, \mathrm{n}=31)$ were anaesthetized with intravenous sodium thiopental $\left(25 \mathrm{mg} \cdot \mathrm{kg}^{-1}\right)$, followed by a continuous thiopental infusion (4-6 $\left.\mathrm{mg} \cdot \mathrm{kg}^{-1} \cdot \mathrm{h}\right)$, and supplemented with intravenous fentanyl citrate $(25-50 \mu \mathrm{g})$ given every 15-30 min. Dogs were intubated and ventilated with room air, via a constant volume ventilator $\left(17 \mathrm{ml} \cdot \mathrm{kg}^{-1}\right)$, to an end-tidal $\mathrm{CO}_{2}$ of approximately $4.5 \%$. Rectal temperature was monitored and body temperature was maintained with a warming pad. Heart rate and blood pressure were monitored with a Datascope Accutorr throughout the course of each experiment. Fibreoptic bronchoscopes (Olympus BFA4B2, $5.5 \mathrm{~mm}$ ) were inserted through ports in an endotracheal tube and were used to obstruct two contralateral sublobar segments (fig. 1). Pressure at the tip of the bronchoscopes $(\mathrm{Pb})$ was measured via one lumen of a dual lumen catheter threaded through the suction port of each bronchoscope. Compressed, dry, room temperature air containing $5 \% \quad \mathrm{CO}_{2}$ was delivered at 200 $\mathrm{ml} \cdot \mathrm{min}^{-1}$ through the other lumen and into a wedged segment. Collateral system resistance (Rcs) was determined at functional residual capacity, when $\mathrm{Pb}$ achieved a plateau, and the pressure (PA) in the surrounding

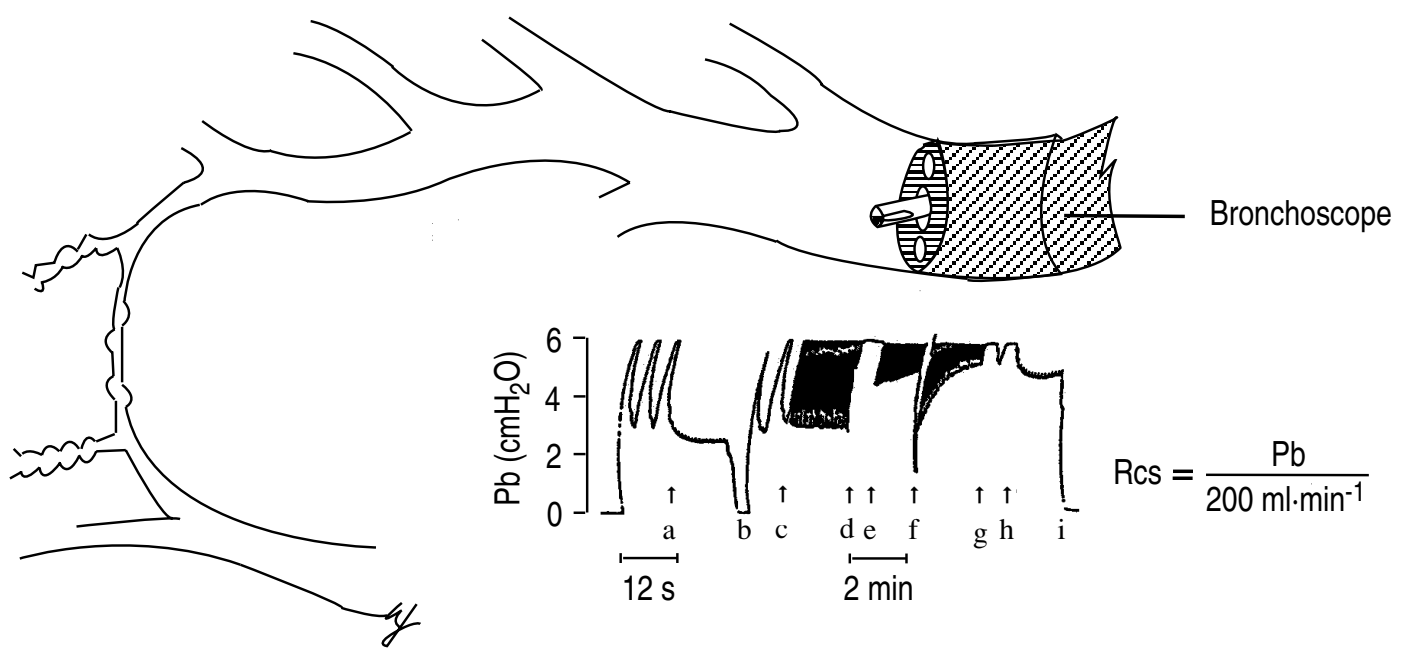

Fig. 1. - Measurement of collateral resistance (Rcs). The diagram depicts the tip of a bronchoscope wedged in a $5.5 \mathrm{~mm}$ airway. A $5 \mathrm{~F}$ catheter protrudes from its port and is used to deliver $5 \% \mathrm{CO}_{2}$ in air $\left(200 \mathrm{ml} \cdot \mathrm{min}^{-1}\right)$ to the wedged sublobar segment, and monitor pressure at the tip of the bronchoscope $(\mathrm{Pb})$. Respiratory bronchioles and alveolar ducts are believed to provide the pathways for collateral flow [29]. The record of $\mathrm{Pb}$ was obtained before, during, and immediately after dry air challenge. Initially, the recorder speed was set at $10 \mathrm{~cm} \cdot \mathrm{min}^{-1}$ and changes in $\mathrm{Pb}$ can

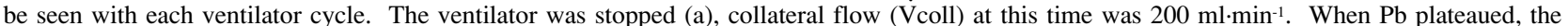
transducer was opened to atmospheric pressure (b). The recorder speed was then slowed to $1 \mathrm{~cm} \cdot \mathrm{min}^{-1}$ (c). Airflow was increased (d) to 1,500 $\mathrm{ml} \cdot \mathrm{min}^{-1}$ for $2 \mathrm{~min}$. Pb went off scale (d) and the gain was reduced by $50 \%$ (e). V to its original setting (f). A gradual rise in end-expiratory $\mathrm{Pb}$ can be seen during the first 2 min postchallenge. The recorder speed was again increased to $10 \mathrm{~cm} \cdot \mathrm{min}^{-1}(\mathrm{~g})$ and the ventilator was stopped at functional residual capacity (FRC) (h). Note that Pb plateaued at a higher level than when the ventilator was stopped at (a). Zero is again checked at (i). Thus, $\mathrm{Rcs}\left(\mathrm{cmH}_{2} \mathrm{O} \cdot \mathrm{ml}^{-1} \cdot \mathrm{s}\right)$ is determined at FRC, when Pb plateaus, and the pressure in the surrounding unobstructed lung equals zero. 
unobstructed lung equalled zero. Thus, Rcs was calculated by dividing the pressure at the tip of the bronchoscope by baseline airflow, i.e. $\mathrm{Rcs}=(\mathrm{Pb}-\mathrm{Pa}) / 200$ $\mathrm{ml} \cdot \mathrm{min}^{-1}=\mathrm{Pb} / 200 \mathrm{ml} \cdot \mathrm{min}^{-1}$. Rcs data are presented in $\mathrm{cmH}_{2} \mathrm{O} \cdot \mathrm{ml}^{-1} \cdot \mathrm{s}$.

\section{Dry airflow challenge}

Bronchoconstriction was induced by increasing the flow of $5 \% \mathrm{CO}_{2}$ in dry air from $200 \mathrm{ml} \cdot \mathrm{min}^{-1}$ to 1,500 $\mathrm{ml} \cdot \mathrm{min}^{-1}$ for $2 \mathrm{~min}$. At the end of the $2 \mathrm{~min}$ period, flow rate was returned to $200 \mathrm{ml} \cdot \mathrm{min}^{-1}$ and Rcs was monitored until prechallenge values were re-established.

\section{Hypertonic aerosol challenge}

Solutions were freshly prepared for each experiment and osmolality was confirmed using a Wescor vapour pressure osmometer. Either Hank's balanced salt solution (HBSS) made hypertonic with mannitol $(875 \pm 2$ $\left.\mathrm{mOsm} \cdot \mathrm{kg}^{-1}, \mathrm{pH}=7.3, \mathrm{~N}=10\right)$, or $14.4 \% \mathrm{NaCl}(4,446 \pm 36$ $\left.\mathrm{mOsm} \cdot \mathrm{kg}^{-1}, \mathrm{pH}=7.4, \mathrm{~N}=10\right)$ was aerosolized using a DeVilbiss Ultra Neb 100 and delivered through the bronchoscope to the obstructed sublobar segment. The 900 mOsm solution was used in studies involving repeated challenge, because we were concerned that a higher concentration would not allow the sublobar segment to recover in sufficient time to complete the experiment. We used $\sim 4,400$ mOsm saline because: 1 ) mannitol would not remain in solution at the desired concentration; and 2) canine Rcs does not respond differently to these two hypertonic solutions [23]. The dual-lumen catheter was temporarily removed from the bronchoscope and, depending on the sensitivity of the dog, aerosol was delivered in air with $5 \% \mathrm{CO}_{2}$ at 200 $\mathrm{ml} \cdot \mathrm{min}^{-1}$ for either a 1 or $2 \mathrm{~min}$ period.

\section{Bronchoalveolar lavage and differential cell counts}

Lavage was performed $5 \mathrm{~min}$ postchallenge using two $40 \mathrm{ml}$ and one $20 \mathrm{ml}$ aliquots of warm $\left(37^{\circ} \mathrm{C}\right)$ isotonic HBSS $\left(\sim 300 \mathrm{mOsm} \cdot \mathrm{kg}^{-1}\right)$ or hypertonic mannitolHBSS $\left(\sim 900 \mathrm{mOsm} \cdot \mathrm{kg}^{-1}\right)$. Fluid was delivered via the suction port of the bronchoscope and was gently suctioned from the wedged segment using a $20 \mathrm{ml}$ syringe. Lavage samples were stored at $4^{\circ} \mathrm{C}$ until the conclusion of the experiment, and centrifuged at $4^{\circ} \mathrm{C}$ for 10 min at $1,300 \mathrm{rpm}$. The cell pellet from a $5 \mathrm{ml}$ sample was resuspended in $1 \mathrm{ml}$ of supernatant, and a $10 \mu \mathrm{l} \mathrm{sam-}$ ple was placed on a haemocytometer to determine total cell number. A cytospin was used to prepare slides from this concentrated cell sample, and blinded differential cell counts of macrophages, lymphocytes, neutrophils, eosinophils, and epithelial cells were performed after staining with Diff-Quik. The trypan blue exclusion method was used to evaluate cell viability. The bulk of the supernatant was saved for mediator assays. Mediator concentrations in BALF
Determinations of prostaglandin $\mathrm{D}_{2}\left(\mathrm{PGD}_{2}\right), \mathrm{F}_{2 \alpha}\left(\mathrm{PGF}_{2 \alpha}\right)$, and thromboxane $\mathrm{B}_{2}\left(\mathrm{TxB}_{2}\right)$ were carried out as follows: BALF sample was concentrated using a Sep-Pak $\mathrm{C}_{18}$ cartridge (Waters Assoc., Milford, MA, USA) and eluted in $4 \mathrm{ml}$ of methanol. This sample was centrifuged and the supernatant evaporated to dryness. The dried sample was then reconstituted to $1.0 \mathrm{ml}$ with $0.1 \%$ gelatin-phosphate buffered saline. The mediator was then measured using a competitive radioimmunoassay (RIA) system, as described previously [11, 30]. Assays were sensitive from 5-20 pg. $0.1 \mathrm{ml}^{-1}$ and crossreactivity of all antibodies was $<1 \%$ with $\mathrm{PGE}_{1}, \mathrm{PGE}_{2}$, 6-keto $\mathrm{PGF}_{1}, \mathrm{PGF}_{2 \alpha}$, and $\mathrm{TxB}_{2}$ [31]. Determinations of $\mathrm{PGD}_{2}, \mathrm{PGF}_{2 \alpha}$, and $\mathrm{TxB}_{2}$ were confirmed using capillary gas chromatography-mass spectrometric (GC-MS) analysis as described by LIU et al. [32]. In the first series of experiments, samples were prepared by adding deuterated internal standards to the $0.4 \mathrm{ml}$ of methanol extracted sample, evaporated under a nitrogen stream and the residue containing the eluted prostanoids was treated with $30 \mu \mathrm{l}$ of $2 \%$ methoxyamine $\mathrm{HCl}$ dissolved in pyridine for $18-24 \mathrm{~h}\left(20^{\circ} \mathrm{C}\right)$. Oximated samples were stored at $-70^{\circ} \mathrm{C}$ until further derivatization immediately prior to GC-MS analysis. These samples provided only qualitative confirmation of the presence of specific prostanoids in BALF. In the second series of experiments, deuterated internal standards were added to the BALF prior to extraction using Sep-Pak cartridges. Assays performed in this manner provided quantitative determination of prostanoids in BALF. The minimum limit of detection was $0.1-0.2 \mathrm{pg} \cdot \mathrm{ml}^{-1}$ BALF [32].

\section{Protein analysis of $B A L F$}

Protein assays (Bio-Rad) were carried out in duplicate using $100 \mu \mathrm{l}$ samples of BALF. Prepared samples were read spectrophotometrically and evaluated using an albumin standard curve.

\section{Statistical analyses}

Rcs data were analysed using a repeated measures analysis of variance (ANOVA) and Duncan's multiple range test. Lavage cell and mediator data were compared using either a Wilcoxon signed-ranks test or a Kruskal-Wallis one-way ANOVA. Spearman's rank correlation $\left(r_{s}\right)$ analysis was used to examine the relationship between dry air and hypertonic-induced responses in the canine lung periphery. All values represent mean \pm SEM. Note that a paired design was used for all experiments and all statistical analyses were performed on absolute values and focused on within-animal variation. However, the SEM bars in our figures depict between-animal variation. Statistical significance was judged at $\mathrm{p}<0.05$ in all cases. Experimental protocols 
Effect of airway drying on hypertonic aerosol-induced bronchoconstriction. Two bronchoscopes were simultaneously wedged in contralateral sublobar segments of anaesthetized, ventilated, male mongrel dogs. After establishing a stable baseline, one wedged sublobar segment was exposed for 2 min to dry air $(1,500$ $\left.\mathrm{ml} \cdot \mathrm{min}^{-1}\right)$. Rcs was recorded at $30 \mathrm{~s}, 2$ and $5 \mathrm{~min}$ after exposure, and then every $5 \mathrm{~min}$ until the baseline was re-established. Then, a second challenge was performed for $60 \mathrm{~s}$ using a hypertonic aerosol $\left(\sim 900 \mathrm{mOsm} \cdot \mathrm{kg}^{-1}\right)$. Rcs was again recorded at $30 \mathrm{~s}, 2$ and $5 \mathrm{~min}$, and then every $5 \mathrm{~min}$ thereafter. Finally, a third challenge was performed, identical to the first using dry air ( $n=6$ sublobar segments in five dogs).

Effect of hypertonic aerosol on dry air-induced bronchoconstriction. The contralateral lung described above was used to perform an experiment similar to the one above except for a reversal in the order of exposure. After an initial exposure and response to a hypertonic solution, dry air challenge was performed, and was followed by another hypertonic-aerosol challenge identical to the first ( $n=6$ sublobar segments in six dogs).

Comparison of dry air and $14.4 \% \mathrm{NaCl}$ aerosol challenge. Ten sublobar segments in six dogs were exposed to a $14.4 \%\left(\sim 4,400 \mathrm{mOsm} \cdot \mathrm{kg}^{-1}\right)$ aerosol of $\mathrm{NaCl}$ for $60 \mathrm{~s}$. After the peripheral airway response had subsided and the baseline was re-established, the same wedged segment was exposed to dry air $\left(1,500 \mathrm{ml} \cdot \mathrm{min}^{-1}\right)$ for 2 min. The sequence of aerosol and dry air challenges was randomly determined for each dog tested.

Effect of dry air and $14.4 \% \mathrm{NaCl}$ aerosol challenge on $B A L F$ cell profiles and mediator concentrations. A series of eight experimental trials were carried out in eight different animals, in which two contralateral segments in each dog were simultaneously wedged with a bronchoscope. One randomly selected side was exposed to a $60 \mathrm{~s} 14.4 \% \mathrm{NaCl}$ aerosol challenge, the other to a $2 \mathrm{~min} 1,500 \mathrm{ml} \cdot \mathrm{min}^{-1}$ dry air challenge. Rcs was recorded at 2 and $5 \mathrm{~min}$ postchallenge and the lung was lavaged immediately thereafter. After removing the two bronchoscopes, a third scope was wedged in a control segment undisturbed by the preceding procedure, and the sublobar segment was lavaged.

Effect of cyclo-oxygenase inhibition on $14.4 \% \mathrm{NaCl}$ aerosol challenge. Four dogs (6 lobes) were challenged with hypertonic saline aerosol before and after indomethacin $\left(5 \mathrm{mg} \cdot \mathrm{kg}^{-1}, i . v\right.$.). This dose had previously been shown to significantly decrease AIB in the canine lung periphery $[11,13]$. Sublobar segments were exposed to either 60 or $120 \mathrm{~s}$ of hypertonic aerosol, depending on the sensitivity of the animal.

Effect of hypertonicity on BALF cell profiles and mediator concentrations. Seven trials were performed in seven different animals, in which segments were wedged and immediately lavaged with isotonic HBSS $\left(\sim 300 \mathrm{mOsm} \cdot \mathrm{kg}^{-1}\right)$. The contralateral lung was then lavaged with hypertonic mannitol-HBSS $\left(\sim 900 \mathrm{mOsm} \cdot \mathrm{kg}^{-1}\right)$.

\section{Results}

Effect of airway drying on hypertonic aerosol-induced

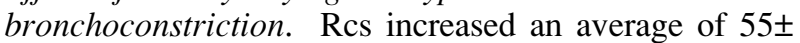
$14 \%(\mathrm{p}<0.01)$ above baseline $5 \mathrm{~min}$ after the first dry air challenge, $23 \pm 3 \%(\mathrm{p}<0.05) 30 \mathrm{~s}$ after a subsequent aerosol challenge with hypertonic mannitol-HBSS, and $47 \pm 13 \%(\mathrm{p}<0.01)$ after the second dry air challenge of the same sublobar segment (fig. 2a). Although peak Rcs after each dry air challenge was significantly greater $(p<0.01)$ than the intervening HIB, the magnitude of AIB before and after exposure to hypertonic aerosol was similar. Time separating the initiation of the first and second, and the second and third challenges was $64 \pm 14$ and $23 \pm 3 \mathrm{~min}$, respectively. Note that the differences in time separating these challenges reflect the magnitude of the preceding response, and thus the recovery time.

Effect of hypertonic aerosol on dry air-induced bronchoconstriction. Hypertonic mannitol-HBSS aerosols administered before and after dry air challenge increased Rcs $27 \pm 5 \%$ and $24 \pm 10 \%(p<0.05)$ above baseline $30 \mathrm{~s}$ after exposure, respectively (fig $2 \mathrm{~b}$ ). The interposed dry air challenge increased Rcs $74 \pm 27 \%(p<0.01)$ above baseline at $2 \mathrm{~min}$ postexposure. Although peak Rcs after each hypertonic aerosol challenge was significantly less $(p<0.01)$ than the intervening AIB, the magnitude of HIB before and after exposure to dry air was similar. Time separating the initiation of the first and second, and the second and third challenges was $41 \pm 7$ and $65 \pm 19 \mathrm{~min}$, respectively. Spearman's rank analysis of the combined data, depicted in figure $2 a$ and $b$, revealed a significant correlation between HIB and AIB when Rcs 30 s after aerosol challenge was compared to Rcs 5 min after dry air challenge $\left(r_{s}=0.79 ; \mathrm{p}<0.001 ; n=10\right)$.

Comparison of dry air and $14.4 \% \mathrm{NaCl}$ aerosol challenge. Hypertonic saline aerosol and dry air challenge increased Rcs an average of $122 \pm 36 \%$ and $49 \pm 7 \%$ $(\mathrm{p}<0.01)$ above baseline $30 \mathrm{~s}$ and $5 \mathrm{~min}$ postchallenge, respectively (fig. 3a). Response to $14.4 \% \mathrm{NaCl}$ was significantly elevated throughout the $15 \mathrm{~min}$ postchallenge period. A significant correlation was found between HIB and AIB when Rcs $30 \mathrm{~s}$ after aerosol challenge was compared to Rcs 5 min after dry air challenge (fig. 3b) $\left(\mathrm{r}_{\mathrm{s}}=0.90 ; \mathrm{p}<0.001\right)$.

Effect of dry air and $14.4 \% \mathrm{NaCl}$ aerosol challenge on BALF cell profiles and mediator concentrations. In this series of eight experiments, bronchoalveolar lavage was performed 5 min after exposure to either dry air or hypertonic saline aerosol. Rcs increased $56 \pm 20 \% 5 \mathrm{~min}$ after dry air challenge, whereas hypertonic aerosol challenge increased Rcs an average of $77 \pm 14 \% 30 \mathrm{~s}$ after exposure. An average of $45 \pm 4$ and $38 \pm 3 \mathrm{ml}$ of fluid was recovered from dry air and hypertonic aerosol expo- 

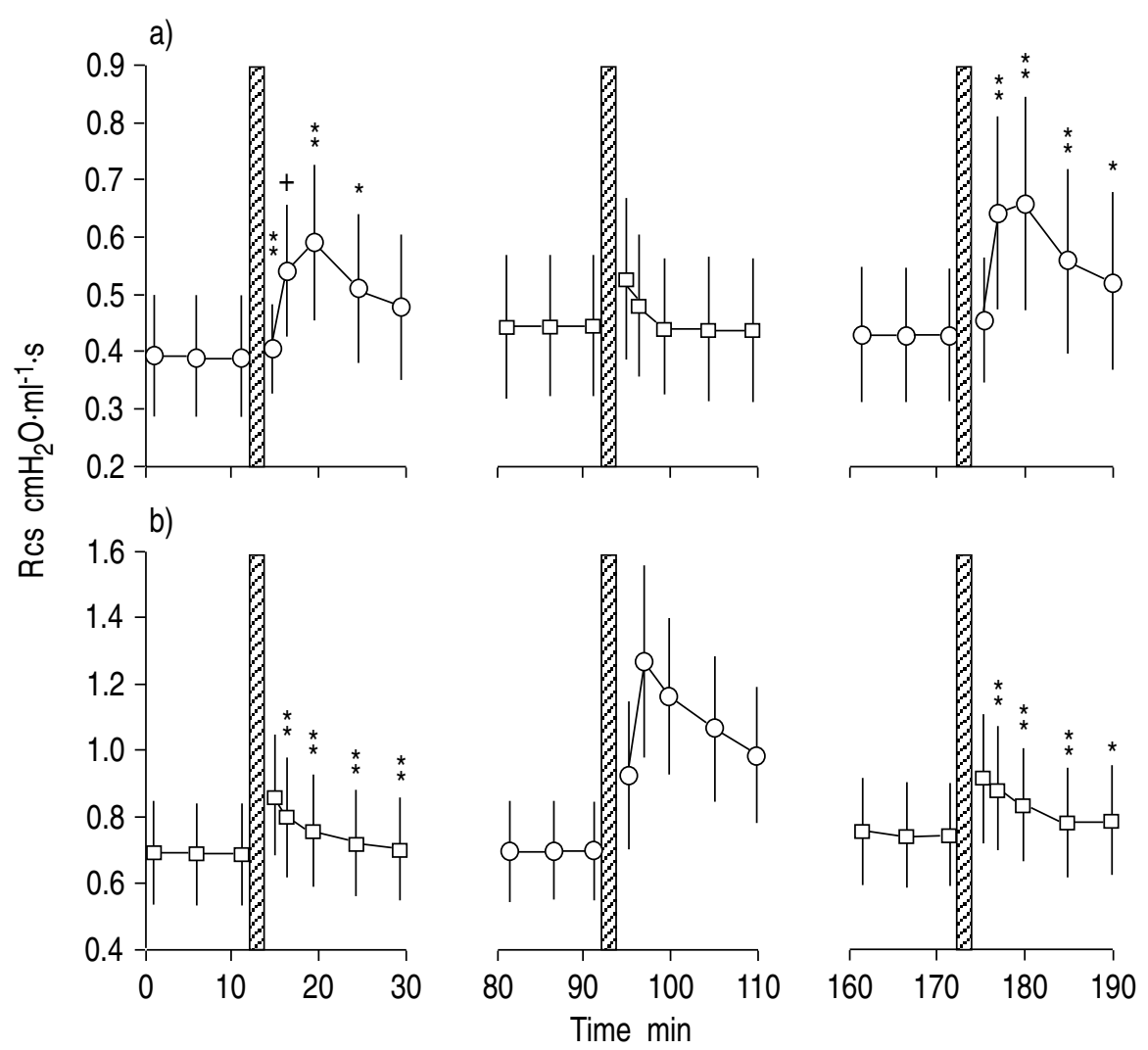

Fig. 2. - a) Collateral system resistance (Rcs) for two identical $2 \mathrm{~min}$ dry air challenges (—o-: $\left.1,500 \mathrm{ml} \cdot \mathrm{min}^{-1}\right)$ separated by a $60 \mathrm{~s}$ hypertonic aerosol challenge (- $-\mathbf{\square}$ : $~ 900 \mathrm{mOsm} \cdot \mathrm{kg}^{-1}$ ) in the same sublobar segment. b) Rcs for two identical hypertonic aerosol challenges ( 900 mOsm $\left.\cdot \mathrm{kg}^{-1}\right)$ separated by a 2 min dry air challenge $\left(1,500 \mathrm{ml} \cdot \mathrm{min}^{-1}\right)$ in the same sublobar segment. Breaks in the $\mathrm{x}$-axis reflect the variable time separating a challenge (see Results). Shaded bars represent a period of challenge $(\mathrm{n}=6)$. Values represent mean \pm SEM. $*: \mathrm{p}=0.05$ and $* *: \mathrm{p}=0.01$ level of significance when comparing dry air to hypertonic aerosol. ${ }^{+}: 0.05$ level of significance when comparing the two dry air responses.

a)

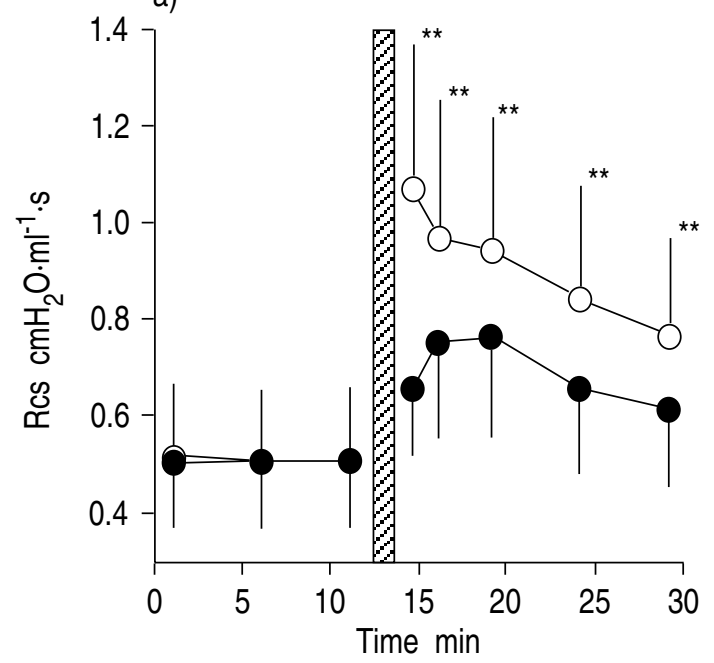

b)

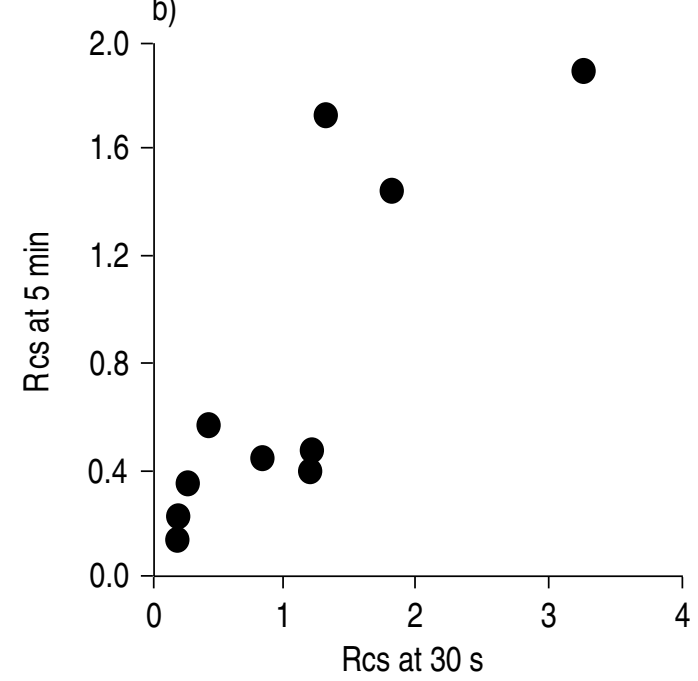

Fig. 3. - a) Collateral system resistance (Rcs) in response to a $2 \mathrm{~min} 1,500 \mathrm{ml} \cdot \mathrm{min}^{-1}$ dry air challenge (- aerosol challenge (- - ) in the same sublobar segment ( $\mathrm{n}=10$ lungs, 6 dogs). Values respresent mean \pm SEM. **: $\mathrm{p}=0.01$. b) Correlation between Rcs $30 \mathrm{~s}$ after challenge with hypertonic $\mathrm{NaCl}(\operatorname{Rcs} 30)$ and $\mathrm{Rcs} 5 \mathrm{~min}$ after dry air challenge $(\operatorname{Rcs} 5)\left(\mathrm{r}_{\mathrm{s}}=0.90 ; \mathrm{p}<0.0001\right)$.

sed segments, respectively. This was not significantly different $(p=0.316)$ from the $45 \pm 5 \mathrm{ml}$ recovered from control segments. Total cells $\cdot \mathrm{ml}^{-1}$ of BALF recovered in each of the three groups were also similar $(p=0.976)$. Cell viability was not significantly different $(\mathrm{p}=0.136)$ in BALF from control $(97 \pm 1 \%)$, dry air $(95 \pm 1 \%)$, or hypertonic aerosol $(97 \pm 1 \%)$ exposed segments. Macrophages $(46 \pm 3 \%, n=24)$, lymphocytes $(17 \pm 2 \%)$, polymorphonuclear leucocytes $(16 \pm 2 \%)$, and eosinophils $(7 \pm 1 \%)$ were not significantly different among the three treatment groups (fig. 4a). In contrast, the number of epithelial cells recovered from dry air challenged 
a)

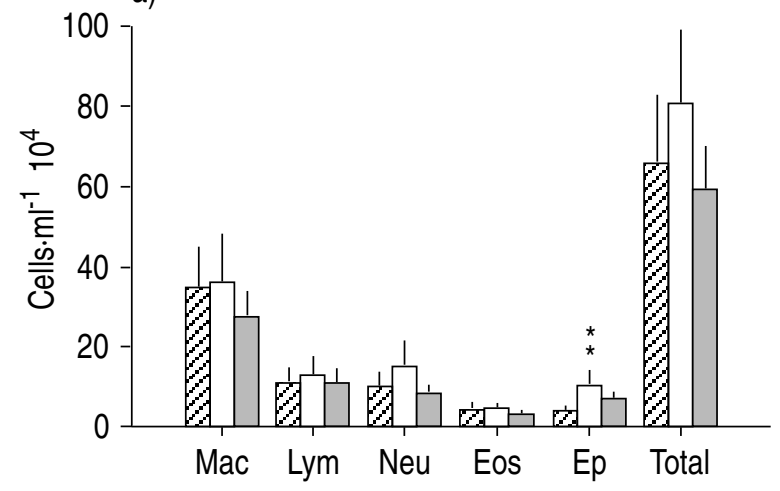

b)

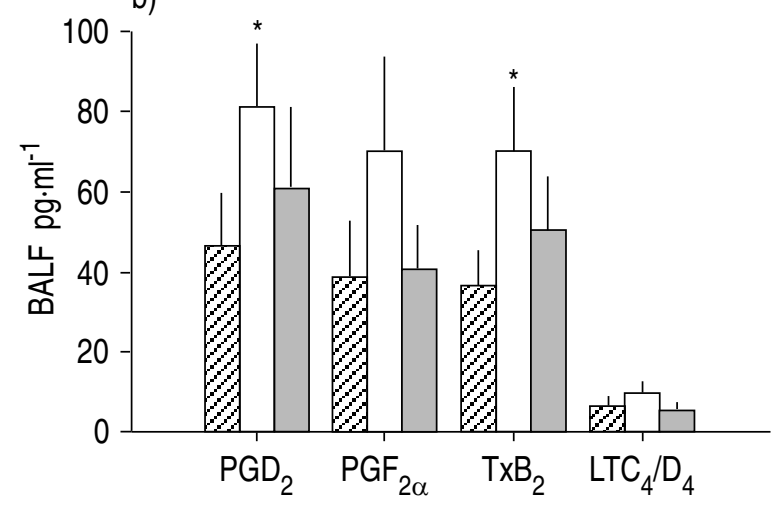

Fig. 4. - a) Differential cell counts expressed as cells $\cdot \mathrm{ml}^{-1}$ of lavage fluid recovered from control, hypertonic $\mathrm{NaCl}$, and dry air exposed sublobar segments 5 min postchallenge. Mac: macrophage; Lym: lymphocyte; Neu: neutrophil; Eos: eosinophil; Ep: epithelial cell. b) Concentrations of prostaglandin $\mathrm{D}_{2}\left(\mathrm{PGD}_{2}\right)$, prostaglandin $\mathrm{F}_{2 \alpha}\left(\mathrm{PGF}_{2 \alpha}\right)$, thromboxane $\mathrm{B}_{2}\left(\mathrm{TxB}_{2}\right)$ and leukotriene $\mathrm{C}_{4} / \mathrm{D}_{4}$ in bronchoalveolar lavage fluid (BALF) recovered in "A" (n=8). $\square$ : control; $\square$ : dry air; $\square$ : $14.4 \% \mathrm{NaCl}$. Values represent mean \pm SEM. *: $\mathrm{p}=0.05$; **: $\mathrm{p}=0.01$.

segments $(14 \pm 2 \%, \mathrm{n}=8)$ was significantly increased $(\mathrm{p}<0.001)$ when compared to unchallenged control segments $(8 \pm 2 \%)$ (fig. $4 \mathrm{a})$. The number of epithelial cells recovered from hypertonic aerosol exposed segments $(16 \pm 4 \%)$ tended to be greater than control $(\mathrm{p}=0.071)$, and were not significantly different from dry air exposed segments $(\mathrm{p}=0.417)$. RIA of lavage samples detected significantly greater concentrations of $\mathrm{PGD}_{2}(\mathrm{p}=$ $0.021)$ and $\mathrm{TxB}_{2}(\mathrm{p}=0.040)$ in dry air challenged segments when compared to BALF from unchallenged segments (fig. 4b). $\mathrm{PGF}_{2 \alpha}(\mathrm{p}=0.117)$ and $\mathrm{LTC}_{4}(\mathrm{p}=0.559)$ were not significantly elevated. $\mathrm{PGD}_{2}(\mathrm{p}=0.071), \mathrm{PGF}_{2 \alpha}$ $(\mathrm{p}=0.180), \mathrm{TxB}_{2}(\mathrm{p}=0.181)$, and $\mathrm{LTC}_{4}$ in hypertonic aerosol exposed segments were not significantly different from control. The presence of these specific prostanoids was confirmed via GC-MS analysis. The concentration of protein in lavage samples from control $\left(64 \pm 17 \mu \mathrm{g} \cdot \mathrm{ml}^{-1}\right)$, dry air $\left(100 \pm 24 \mu \mathrm{g} \cdot \mathrm{ml}^{-1}\right)$, and $\mathrm{NaCl}\left(59 \pm 16 \mu \mathrm{g} \cdot \mathrm{ml}^{-1}\right)$ exposed segments did not differ significantly $(\mathrm{p}=0.295)$.

Effect of cyclo-oxygenase inhibition on $14.4 \% \mathrm{NaCl}$ aerosol challenge. Hypertonic aerosol challenge in six lungs significantly $(\mathrm{p}<0.01)$ increased Rcs $67 \pm 7 \%$ above baseline, $30 \mathrm{~s}$ after challenge. Rcs returned to $0.52 \pm 0.1$ $\mathrm{cmH}_{2} \mathrm{O} \cdot \mathrm{ml}^{-1} \cdot \mathrm{s}$, which was similar to the original baseline $\left(0.53 \pm 0.1 \mathrm{cmH}_{2} \mathrm{O} \cdot \mathrm{ml}^{-1} \cdot \mathrm{s}\right)$. Rcs subsequently increased a)

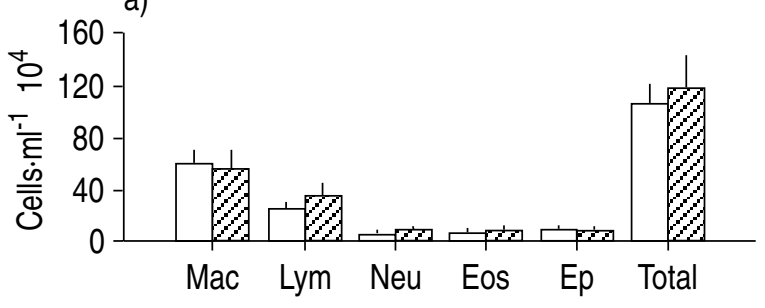

b)

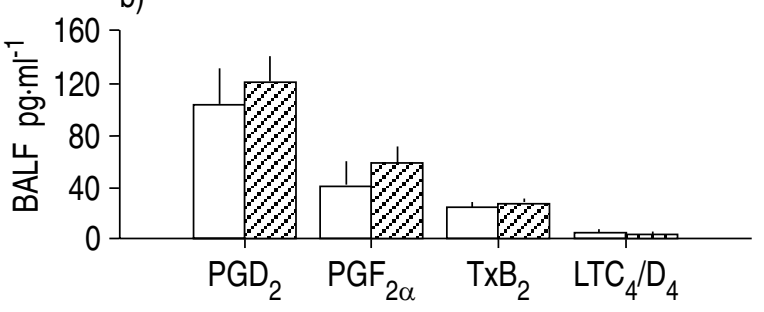

c)

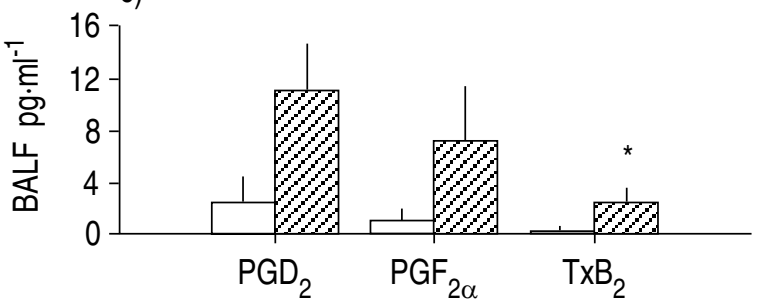

Fig. 5. - a) Differential cell counts expressed as cells. $\mathrm{ml}^{-1}$ of lavage fluid recovered in isotonic $\left(\sim 300 \mathrm{mOsm} \cdot \mathrm{kg}^{-1}\right)$ and hypertonic $(\sim 900$ mOsm $\cdot \mathrm{kg}^{-1}$ ) lavage fluid. b) Concentrations of $\mathrm{PGD}_{2}, \mathrm{PGF}_{2 \alpha}$, and $\mathrm{TxB}_{2}$ and $\mathrm{LTC}_{4} / \mathrm{D}_{4}$ in lavage fluid recovered in "a" determined via radioimmunoassay. c) Concentrations of $\mathrm{PGD}_{2}, \mathrm{PGF}_{2 \alpha}$, and $\mathrm{TxB}_{2}$ in lavage fluid recovered in "a" determined by capillary gas chromatography-mass spectrometry $(\mathrm{n}=7) . \square: \sim 300 \mathrm{mOsm} \cdot \mathrm{kg}^{-1} ; \square: \sim 900$ $\mathrm{mOsm} \cdot \mathrm{kg}^{-1}$. For abbreviations see legend to figure 4 . Values represent mean \pm SEM. *: $\mathrm{p}=0.05$.

$65 \pm 15 \% 30 \mathrm{~s}$ after the post-indomethacin challenge, which was not significantly different $(p=0.42)$ from the preceding response. Indomethacin did not significantly affect heart rate $(71 \pm 5$ vs $69 \pm 4 \mathrm{bpm} ; \mathrm{p}=0.30)$ or mean arterial pressure $(108 \pm 9$ vs $105 \pm 11 \mathrm{mmHg}$; $\mathrm{p}=0.59)$.

Effect of hypertonicity on BALF cell profiles and mediator concentrations. An average of $94 \pm 7 \mathrm{ml}$ of fluid was recovered from sublobar segments of seven dogs lavaged with $\sim 900 \mathrm{mOsm} \cdot \mathrm{kg}^{-1}$ fluid. This was significantly more than the $60 \pm 8 \mathrm{ml}$ of fluid recovered from the contralateral lobe when using $\sim 300 \mathrm{mOsm} \cdot \mathrm{kg}^{-1}$ fluid for BALF. Total cells $\cdot \mathrm{ml}^{-1}$ of BALF fluid recovered from isotonic and hypertonic lavage groups were not significantly different $(\mathrm{p}=0.466)$. Cell viability was also similar $(\mathrm{p}=0.136)$ for segments lavaged with isotonic $(94 \pm 1 \%)$ and hypertonic $(90 \pm 3 \%)$ fluids. No differences were evident between macrophages $(50 \pm 2 \%$, $\mathrm{n}=14)$, lymphocytes $(27 \pm 2 \%)$, polymorphonuclear leucocytes $(7 \pm 1 \%)$, eosinophils $(7 \pm 2 \%)$, and epithelial cells $(9 \pm 1 \%)$ recovered in either BALF sample (fig. 5a). Although RIA of lavage samples did not detect significantly different concentrations of $\mathrm{PGD}_{2}(\mathrm{p}=0.176), \mathrm{PGF}_{2 \alpha}$ $(\mathrm{p}=0.102), \mathrm{TxB}_{2}(\mathrm{p}=0.417)$, and $\mathrm{LTC}_{4}(\mathrm{p}=0.338)$ in isotonic and hypertonic BALF (fig. 5b), analysis of prostanoids using GC-MS did reveal some significant 
differences (fig. 5c): $\mathrm{PGD}_{2}(\mathrm{p}=0.071), \mathrm{PGF}_{2 \alpha}(\mathrm{p}=0.053$ ), and $\mathrm{TxB}_{2}(\mathrm{p}=0.050)$. The concentration of protein from isotonic $\left(137 \pm 21 \mu \mathrm{g} \cdot \mathrm{ml}^{-1}\right)$ and hypertonic $(204 \pm 38$ $\left.\mu \mathrm{g} \cdot \mathrm{ml}^{-1}\right)$ lavaged segments did not differ significantly $(\mathrm{p}=0.076)$.

\section{Discussion}

Previous studies have demonstrated that canine peripheral airways were nonrefractory to dry air [10, 11, 13] and hypertonic aerosol challenges [23]. In this study, we found that AIB was unaffected by a preceding hypertonic aerosol challenge (fig. 2a), and HIB was unaltered by a preceding dry air challenge (fig. 2b). Thus, within the 20-60 min separating the two challenges in this study, canine peripheral airways did not exhibit cross-refractoriness to these stimuli (fig. 2). These data are consistent with those of BELCHER et al. [27], who reported that $60 \%$ of the asthmatic subjects in their study were not refractory to exercise or hypertonic $\mathrm{NaCl}$, and were not cross-refractory to these stimuli. The remaining $40 \%$ of their subjects were refractory to exercise and hypertonic aerosol challenge, and were cross-refractory to these stimuli. Based on this phenomenon of cross-refractoriness, it was suggested that hypertonicity and exercise initiated bronchoconstriction through a common final pathway. Regardless of whether the mechanism responsible for refractoriness is related to the initiation of either AIB or HIB, this relationship is not evident either in our model or in individuals exhibiting nonrefractory asthma.

AIB and HIB in canine peripheral airways were significantly correlated regardless of whether $\sim 900$ mOsm $\cdot \mathrm{kg}^{-1}$ hypertonic mannitol (see Results, fig. 2, and [23]) or $\sim 4,400 \mathrm{mOsm} \cdot \mathrm{kg}^{-1}$ hypertonic $\mathrm{NaCl}$ (fig. 3) was used for comparison with responses to dry air. We previously suggested that the marked differences in the magnitude and time-course of HIB and AIB as seen in figure 2 and figure 3 , respectively, were related to the strength of the stimulus produced by each mode of challenge [23]. For a given sublobar segment, differences in the magnitude of the response were indeed dependent on stimulus strength: $\sim 900 \mathrm{mOsm} \cdot \mathrm{kg}^{-1}$ aerosol challenges produced smaller responses than challenge with dry air (fig. 2) [23], and the same dry air challenge elicited a smaller response than challenge with a $\sim 4,400$ mOsm $\cdot \mathrm{kg}^{-1}$ aerosol (fig. 3). However, the marked differences in the time-course of responses produced by hypertonic aerosol and dry air challenge remained, regardless of the concentration of aerosol used for comparison. Although these differences in the time-course of AIB and HIB appear to be unrelated to stimulus strength, they may result from differential activation or inactivation of biochemical pathways by these two stimuli. Airway cooling inhibited AIB and HIB in the canine lung periphery [6-8]. However, unlike AIB, hypertonic aerosol-induced responses normally occur in the absence of airway cooling and peak immediately after exposure $[8,25]$. The fact that transient airway cooling during aerosol challenge slows the development of
HIB [8] is consistent with the hypothesis that during periods of hyperpnoea, airway cooling delays the onset of AIB via an inhibition of mediator release and neuronal activity.

Although mediator release has been implicated in AIB [12, 19, 21, 33] and HIB [34-36], the role of biochemical mediators in the initiation of these responses remains controversial. The protection provided by antihistamines [19, 34, 35], mast cell "stabilizers" [36], cyclooxygenase inhibitors [11, 19], and leukotriene receptor antagonists [21, 37, 38] suggest at least a partial role for these mediators in the development of AIB and HIB. In this study, although leukotrienes were not elevated in BAL after challenge with either dry air or $14.4 \% \mathrm{NaCl}$, MK-0591, a leukotriene biosynthesis inhibitor, significantly attenuated AIB in dogs [20]. The mediation of AIB by metabolites of arachidonic acid has been demonstrated in dogs [11], guinea-pigs [39], and asthmatic humans [19]. However, in this study the inhibition of cyclo-oxygenase with indomethacin was ineffective in attenuating HIB. In contrast, aerosolized indomethacin was reported to inhibit ultrasonically nebulized distilled water (UNDW)-induced airway obstruction in asthmatic subjects [40]. Our results are consistent with those of FINNERTY and co-workers [35], who concluded that prostaglandins played a minor role in the development of HIB in subjects with asthma. The fact that indomethacin does protect against UNDW but does not attenuate responses to hypertonic aerosols suggests that these two stimuli operate via different pathways.

Bronchoalveolar lavage revealed few differences in the composition of cells recovered from control, hypertonic aerosol-, and dry air-challenged sublobar segments (fig. 4a). Epithelial cell numbers in BALF from dry air and hypertonic aerosol exposed regions were similar, although the concentration of epithelial cells was significantly greater than those found in control BALF samples only after dry air challenge (fig. 4a). BALF samples from canine peripheral airways exposed to dry airflow were previously reported to contain more epithelial cells $\cdot \mathrm{ml}^{-1}$ than BALF recovered from either unexposed airways or airways challenged with warm, moist air [11]. This increase in the number of epithelial cells recovered from dry air exposed segments suggests that airway drying caused cell desquamation and increased access to the submucosa. However, neither HIB was enhanced by a preceding dry air challenge, nor was AIB altered by a previous exposure to hypertonic aerosol (fig. 2). This suggests that the mucosal injury implicated by postchallenge BALF samples was insufficient to alter peripheral airway responsiveness. Surprisingly, there was no difference in BALF protein concentrations from control, dry air and $\mathrm{NaCl}$ exposed segments, 5 min after challenge. BALF recovered from asthmatic subjects after $5 \mathrm{~min}$ of isocapnic hyperventilation revealed similar results: although epithelial cell numbers were elevated in BALF, BALF total protein was not increased after challenge [12]. Either BALF total protein is too insensitive to be used as a marker of dry air-induced airway injury, or airway drying transiently alters epithelial cell adhesion, and 
increases the probability that these cells would be washed out during lavage. Note that lavage by itself did not affect epithelial cell recovery (fig. 5a) and did not affect the protein concentration in BALF, even when lavage was performed with hypertonic $\mathrm{NaCl}$.

The release of mediators from inflammatory cells sensitive to transient changes in airway fluid osmolality is believed to initiate AIB and HIB [25, 26, 41]. Mediator release in vitro [4], and in vivo [5, 42] was demonstrated in response to osmotic stress. The analysis of BALF from dry air challenged sublobar segments indicated that the concentrations of both $\mathrm{PGD}_{2}$ and $\mathrm{TxB}_{2}$ were significantly elevated above control (fig. 4b). Mediator concentrations in BALF from hypertonic aerosol challenged segments were not significantly different from control (fig. 4b). We previously suggested that dry air challenge primarily triggered mediator release to increase Rcs over a $5 \mathrm{~min}$ postchallenge period, whereas hypertonic aerosols acted primarily through a vagal reflex to produce peak responses immediately after exposure [23]. Atropine attenuated canine AIB [13] and HIB [23], by 31 and $59 \%$, respectively. In addition, changes in BALF mediator concentrations were considerably more marked after dry air than hypertonic aerosol exposure (fig. 4b). These data are consistent with the hypothesis that dry air and hypertonic aerosols induced airway obstruction through common pathways, but differentially stimulated mediator release and muscarinic activity.

Differences in the concentrations of various mediators recovered in isotonic and hypertonic BALF were not detected using RIA (fig. 5b). Similarly, GRAVELYN et al. [42] reported that RIA did not reveal significant differences in the concentration of mediators in isotonic and hypertonic BALF recovered from asthmatic individuals. However, an increase in the concentration of certain mediators in hypertonic BALF was confirmed in this study with GC-MS (fig. 5c). Although the accuracy of either technique for quantifying these mediators could be questioned, both analyses provided similar qualitative data suggesting that mediator concentrations were moderately elevated in response to hypertonic BALF (fig. 5b and c). Initially, the difficulty in demonstrating a difference in mediator release during isotonic and hypertonic lavage seemed surprising. However, canine tracheal epithelium responded asymmetrically to osmotic challenge in vitro. MAN et al. [43] demonstrated that basolateral membrane osmotic conductivity was greater than that of the apical membrane in response to a $100 \mathrm{mOsm}$ osmotic load. If this was also true in vivo, then the bronchial epithelium may be unaffected by relatively large changes in the osmolality of periciliary fluid. This may account for the fact that the concentration of mediators recovered in $\sim 900 \mathrm{mOsm} \cdot \mathrm{kg}^{-1} \mathrm{BALF}$ was similar to that seen in BALF samples from segments exposed to a $\sim 4,400$ $\mathrm{mOsm} \cdot \mathrm{kg}^{-1}$ aerosol challenge (fig. $4 \mathrm{~b}$ and $5 \mathrm{~b}$ ). Differences did exist in peripheral airway responses to dry air and hypertonic challenge, and mediator release appeared to be more prominent in response to the former rather than the latter.

In summary, canine peripheral airways did not exhi- bit cross-refractoriness to either dry air or hypertonic aerosols. However, hypertonic aerosols produced varying degrees of obstruction, and these responses were correlated with responses to dry air challenge. Unlike differences in the magnitude of AIB and HIB, the marked difference in time-course was not dependent on stimulus strength. Epithelial cell numbers in BALF from dry air and hypertonic aerosol exposed regions were similar, although the concentration of these cells was greater than control only after dry air challenge. Concentrations of both $\mathrm{PGD}_{2}$ and $\mathrm{TxB}_{2}$ were significantly elevated above control only in dry air-challenged sublobar segments, and mediator concentrations were only moderately elevated in response to hypertonic BALF. Because BALF samples were obtained at $5 \mathrm{~min}$ post AIB and HIB, differences in BALF cell and mediator profiles may reflect differences in the time course of these two responses. However, it is possible either that dry air challenge created local osmotic loads that exceeded the global osmotic stress produced with hypertonic lavage, or that dry air and hypertonic stimuli acted at different levels of a number of simultaneously active biochemical and nervous system pathways. We previously demonstrated that transient cooling during aerosol challenge delayed the onset of HIB and produced a time course similar to AIB [8]. Thus, differences in BALF cell and mediator data may result from either activation or deactivation of temperature sensitive pathways during dry air challenge that are not affected during exposure to a hypertonic aerosol.

Acknowledgements: The authors thank C.E. Stream for his excellent technical assistance and S.R. Kleeberger for the analysis of BALF protein. They gratefully acknowledge the statistical counselling provided by A.W. Kimball Jr, (Johns Hopkins University).

\section{References}

1. Tabka Z, Jebria AB, Guenard H. Effect of breathing dry warm air on respiratory water loss at rest and during exercise. Respir Physiol 1987; 67: 115-125.

2. Smith CM, Anderson SD. Hyperosmolarity as the stimulus to asthma induced by hyperventilation? J Allergy Clin Immunol 1986; 77: 729-736.

3. Argyros GJ, Phillips YY, Rayburn DB, Rosenthal RR, Jaeger JJ. Water loss without heat flux in exercise-induced bronchospasm. Am Rev Respir Dis 1993; 147: 1419-1424.

4. Eggleston PA, Kagey-Sobotka A, Lichtenstein LM. A comparison of the osmotic activation of basophils and human lung mast cells. Am Rev Respir Dis 1987; 135: 1043-1048.

5. Silber G, Proud D, Warner J, et al. In vivo release of inflammatory mediators by hyperosmolar solutions. Am Rev Respir Dis 1988; 137: 606-612.

6. Freed AN, Kelly LJ, Menkes HA. Airflow-induced bronchospasm: imbalance between airway cooling and airway drying. Am Rev Respir Dis 1987; 136: 595-599.

7. Freed AN, Stream CE. Airway cooling: stimulus specific modulation of airway responsiveness in the canine lung periphery. Eur Respir J 1991; 4: 568-574.

8. Freed AN, Fuller SD, Stream CE. Transient airway cooling modulates dry air-induced and hypertonic aerosol-induced bronchoconstriction. Am Rev Respir Dis 
1991; 144: 358-362.

9. McFadden ER, Jr, Lenner KAM, Strohl KP. Postexertional airway rewarming and thermally-induced asthma. $J$ Clin Invest 1986; 78: 18-25.

10. Freed AN, Bromberger-Barnea B, Menkes HA. Dry airinduced constriction in lung periphery: a canine model of exercise-induced asthma. J Appl Physiol 1985; 59: 1986-1990.

11. Freed AN, Peters SP, Menkes HA. Dry air-induced bronchoconstriction: role of epithelium and eicosanoid mediators. J Appl Physiol 1987; 62: 574-581.

12. Pliss LB, Ingenito EP, Ingram RH, Pichurko B. Assessment of bronchoalveolar cell and mediator response to isocapnic hyperpnea in asthma. Am Rev Respir Dis 1990; 142: 73-78.

13. Freed AN, Wang D, Menkes HA. Dry air-induced constriction: effects of pharmacological intervention and temperature. J Appl Physiol 1987; 62: 1794-1800.

14. Teeter JG, Freed AN. Effect of salbutamol on dry airand acetylcholine-induced bronchoconstriction in the canine lung periphery. Eur Respir J 1991; 4: 972-978.

15. Wang D, Chen HI, Chou CL, Hsu K, Freed AN. Terbutaline acts at multiple sites to inhibit bronchoconstriction induced by dry air in canine peripheral airways. $\mathrm{Am}$ Rev Respir Dis 1992; 145: 1295-1300.

16. Wang D, Adkinson NF Jr, Menkes HA, Freed AN. Aminophylline reduces airflow-induced constriction in the canine lung periphery. Am Rev Respir Dis 1988; 137: $31-37$

17. Anderson S, Seale JP, Ferris L, Schoeffel R, Lindsay DA. An evaluation of pharmacotherapy for exerciseinduced asthma. J Allergy Clin Immunol 1979; 64: 612624.

18. O'Byrne PM, Thomson NC, Morris M, Roberts RS, Daniel EE, Hargreave FE. The protective effect of inhaled chlorpheniramine and atropine on bronchoconstriction stimulated by airway cooling. Am Rev Respir Dis 1983; 128: 611-617.

19. Finnerty JP, Holgate ST. Evidence for the roles of histamine and prostaglandins as mediators in exercise-induced asthma: the inhibitory effect of terfenadine and flurbiprofen alone and in combination. Eur Respir J 1990; 3: $540-547$.

20. Omori C, Freed AN. Leukotrienes modulate airflowinduced bronchoconstriction in canine periperal airways. Am Rev Respir Dis 1993; 147: A296.

21. Manning PJ, Richared MD, Watson M, et al. Inhibition of exercise-induced bronchoconstriction by MK-571, a potent leukotriene $\mathrm{D}_{4}$-receptor antagonist. $\mathrm{N} \mathrm{Engl} \mathrm{J} \mathrm{Med}$ 1990; 323: 1736-1739.

22. Belcher NG, Lee TH, Rees PJ. Airway responses to hypertonic saline, exercise and histamine challenges in bronchial asthma. Eur Respir J 1989; 2: 44-48.

23. Freed AN, Yiin KT, Stream CE. Hyperosmotic-induced bronchoconstriction in the canine lung periphery. $J$ Appl Physiol 1989; 67: 2571-2578.

24. Belcher NG, Murdoch RD, Dalton N, et al. A comparison of mediator and catecholamine release between exercise- and hypertonic saline-induced asthma. Am Rev Respir Dis 1988; 137: 1026-1032.

25. Smith CM, Anderson SD. A comparison between the airway response to isocapnic hyperventilation and hypertonic saline in subjects with asthma. Eur Respir $J$ 1989; 2: 36-43.

26. Smith CM, Anderson SD. Inhalational challenge using hypertonic saline in asthmatic subjects: a comparison with responses to hyperpnoea, methacholine and water.
Eur Respir J 1990; 3: 144-151.

27. Belcher NG, Rees PJ, Clark TJH, Lee TH. A comparison of the refractory periods induced by hypertonic airway challenge and exercise in bronchial asthma. Am Rev Respir Dis 1987; 135: 822-825.

28. Freed AN. Regional and temporal variation in canine peripheral lung reponses to dry air. J Appl Physiol 1989; 67(5): 1727-1733.

29. Mitzner W. Collateral Ventilation. In: Crystal R.G., West J.B., eds. The Lung: Scientific Foundations. New York, Raven Press Ltd, 1991; pp. 1053-1063.

30. Adkinson NF. Prostaglandin production by human peripheral blood cells in vitro. J Lab Clin Med 1977; 90: 1043-1053.

31. Schulman ES, Newball HH, Demes LM, Fitzpatrick FA, Adkinson NF Jr. Anaphylactic release of thromboxan $A_{2}$, prostaglandin $D_{2}$, and prostacyclin from human lung parenchyma. Am Rev Respir Dis 1981; 124: 402-406.

32. Liu MC, Bleecker ER, Proud D, McLemore TL, Hubbard WC. Profiling of bisenoic prostaglandins and thromboxane $\mathrm{B}_{2}$ in bronchoalveolar fluid from the lower respiratory tract of human subjects by combined capillary gas chromatography-mass spectrometry. Prostaglandins 1988; 35: 67-79.

33. Crimi E, Balbo A, Milanese M, Miadonna A, Rossi GA, Brusasco V. Airway inflammation and occurrence of delayed bronchoconstriction in exercise-induced asthma. Am Rev Respir Dis 1992; 146: 507-512.

34. Finney MJB, Anderson SD, Black JL. Terfenadine modifies airway narrowing induced by the inhalation of nonisotonic aerosols in subjects with asthma. Am Rev Respir Dis 1990; 141: 1151-1157.

35. Finnerty JP, Wilmot C, Holgate ST. Inhibition of hypertonic saline-induced bronchoconstricton by terfenadine and flurbiprofen. Am Rev Respir Dis 1989; 140: 593-597.

36. Rodwell LT, Anderson SD, DuToit J, Seale JP. Nedocromil sodium inhibits the airway response to hyperosmolar challenge in patients with asthma. Am Rev Respir Dis 1992; 146: 1149-1159.

37. Finnerty JP, Wood-Baker R, Thomson H, Holgate ST. Role of leukotrienes in exercise-induced asthma. Am Rev Respir Dis 1992; 145: 746-749.

38. Robuschi M, Riva E, Fuccella LM, et al. Prevention of exercise-induced bronchoconstriction by a new leukotriene antagonist (SK\&F 104353). Am Rev Respir Dis 1992; 145: 1285-1288.

39. Ingenito EP, Pliss LB, Ingram RH, Pichurko BM. Bronchoalveolar lavage cell and mediator responses to hyperpnea-induced bronchoconstriction in the guineapig. Am Rev Respir Dis 1990; 141: 1162-1166.

40. Bianco S, Vaghi A, Pieroni MG, Robuschi M, Refini RM, Sestini P. Protective activity of inhaled nonsteroidal anti-inflammatory drugs on bronchial responsiveness to ultrasonically nebulized water. J Allergy Clin Immunol 1992; 90: 833-839.

41. Anderson SD, Schoeffel RE, Finney M. Evaluation of ultrasonically nebulised solutions for provocation testing in patients with asthma. Thorax 1983; 38: 284-291.

42. Gravelyn TR, Pan PM, Eschenbacher WL. Mediator release in an isolated airway segment in subject with asthma. Am Rev Respir Dis 1988; 137: 641-646.

43. Man SFP, Hulbert E, Park DSK, Thomason ABR, Hogg JC. Asymmetry of canine tracheal epithelium: osmotically induced changes. J Appl Physiol: Respirat Environ Exercise Physiol 1984; 57: 1338-1346. 